\title{
KORSTOGSTANKENS REFORMULERING I 1600-TALLETS ENGLAND
}

\author{
Morten Brænder
}

\begin{abstract}
ENGLISH ABSTRACT: Traditionally, holy war is considered as a medieval conduct. That view is challenged by the present article. It claims instead that the restatement of the idea of crusading which took place in the puritan movement on the eve of the Civil War united two exceptionally modern elements: The 'worldly asceticism' that refined the strengthening of individual discipline, and the 'realized eschatology' which formed the basis of a mundane notion of the course of history.
\end{abstract}

DANSK RESUME: Traditionelt betragtes hellig krig i en kristen kontekst som en overvejende middelalderlig foreteelse. Denne artikel anfagter denne opfattelse, idet den hovder, at den reformulering af korstogstanken, som fandt sted blandt de engelske puritanere i årene op til borgerkrigens udbrud i 1642, forenede to elementer, der i allerhøjeste grad skulle forme det moderne: Den verdslige askese, der forfinede den individuelle disciplinering, og den realiserede eskatologi, der skabte grundlag for en dennesidig opfattelse af historiens forløb.

KEYWORDS: Puritanism, Holy War, Alexander Leighton, Worldly Asceticism, Realized Eschatology.

Den 16. november 1630 blev lægen og prædikanten Alexander Leighton - efter at være blevet idømt livsvarig flådetjeneste, en astronomisk bøde på $10.000 £$ og frakendt sit præsteembede - ført til Westminster, hvor han blev pisket, fik sit ene næsebor skåret op, sit ene øre hugget af, og som kronen på værket blev den formasteliges kind brændemærket med bogstaverne S.S., en forkortelse for betegnelsen "Sower of Sedition". Fra nu af kunne enhver bogstaveligt talt læse i Leightons ansigt, at her gik en "ufredens sædemand', der i kraft af sine skrifter havde sået splid og derfor udgjorde en trussel mod rigets sikkerhed.

Set i lyset af den grusomhed, menneskelige samfund til alle tider har vist evne til at tilvejebringe, virker beretningen om Leightons lidelser nærmest triviel. Men i historisk henseende er den alligevel interessant. For det første udgjorde torturen af Leighton en helt afgørende begivenhed i det hændelsesforløb, der ledte frem til udbruddet af den engelske borgerkrig, Charles I's henrettelse og etableringen af en teokratisk republik i årene 1648-1660: Leighton var den første puritaner, der under den anglikanske ærkebiskop William Laude blev dømt ved the Star Chamber, Englands forræderidomstol. For det andet er Leighton interessant, fordi vi i hans værk Speculum Belli Sacri, den hellige krigs spejl, fra 1624 finder et klart vidnesbyrd på en afgørende forskydning af 
opfattelsen af krig og religion hos puritanerne i 1600-tallets England. ${ }^{1}$ Det er den forskydning, som udgør omdrejningspunktet i denne artikel.

\section{Den puritanske korstogstanke}

Betegnelsen puritaner er oprindeligt et skældsord, brugt om dem, der ikke mente, at den protestantiske reform, Elizabeth I iværksatte efter sin kroning i 1558, var vidtgående nok og derfor nægtede at følge dens krav om liturgisk uniformitet. Men som så ofte før i historien blev øgenavnet af de socialt ekskluderede betragtet som en hædersbevisning, et tegn på deres særlige status. Puritanisme er en samlebetegnelse, der bortset fra den fælles afvisning af bispedømmet dækker over en række meget forskellige grupperinger, hver med deres kirkesyn. Når betegnelsen alligevel giver mening, skyldes det, at disse forskellige denominationer delte to afgørende fællestræk. For det første så de sig selv som én gruppe, der var fælles om at besidde udvælgelses- eller frelsesbevidsthed (Simpson 1955,2$).{ }^{2}$ Denne bevidsthed, karakteristisk for 1600 -tallets calvinistiske puritanere, blev for det andet - og det er denne artikels centrale pointe - forenet med en 'realiseret eskatologi', en særlig opfattelse af forholdet mellem det dennesidige og det hinsides, som forstærkede idéen om en enhed mellem menighed og samfund i årene op til den engelske borgerkrig.

Det banebrydende studie i puritanernes opfattelse af hellig krig blev udfoldet af Ronald H. Bainton i artiklen "Congregationalism: from the Just War to the Crusade in the Puritan Revolution" fra 1943. Bainton bruger betegnelsen 'korstog' frem for 'hellig krig', og heri vil jeg hævde, at der ligger en afgørende pointe. For hvor hellig krig betegner enhver religiøs legitimering af kollektivt udøvede voldshandlinger - og altså udgør et metabegreb - betragter jeg i forlængelse af Baintons studier korstogstanken som en særlig form for legitimeringsmodus, hvori de religiøse autoriteter ikke alene blåstempler brugen af social voldsanvendelse, men tilskynder den eller endog selv er medvirkende hertil. Ifølge Bainton kan kristendommen forholde sig på tre måder til fænomenet krig: Den kan indtage en pacifistisk holdning, den kan anse krig for at være et nødvendigt onde, hvis udøvelse kan legitimeres med henvisning til retfærdigheden, og den kan endelig betragte krig som en gudvelbehagelig gerning. Det er den sidstnævnte holdning, Bainton hævder er kendetegnende for de klassiske korstog, og som vi genfinder hos 1600-tallets engelske puritanere (Bainton 1943, 250). Det afgørende for Bainton er forskellen på retfærdig krig og korstogstanken. I den retfærdige krig betragtes krigen som et onde, der kun tages i brug med henblik på at overvinde et værre onde. Den hensigt, krigen indledes med, dens 'jus ad bellum', sætter derfor også visse grænser for, hvorledes krigen 'in bello' overhovedet kan føres. Med andre ord: I den retfærdige krig skal der være en vis proportionalitet mellem krigens mål og dens midler. Den hellige krig kendetegnes derimod ved at ophæve dette krigens proportionalitetsprincip. For konfronteret med et mål, som i sagens natur helliger ethvert middel, ophører enhver henvisning til proportionalitet med at have gyldighed. Korstogstankens varemærke er med andre ord dens 'antinomisme': Den hellige krig udspiller sig inden for den hellige

\footnotetext{
'I samme genre er Thomas Adams' The Soudiers Honour (1617), Thomas Suttons The Good Fight of Faith (1624), Thomas Barnes' Vox Belli (1626) og William Gouges Gods Three Arrows (1631) (George 1984, 495).

${ }^{2}$ Til puritanerne regner jeg derfor presbyterianere, kongregationalister og - i modsætning til mere forsigtige definitioner - også kvækere (Vennernes Samfund) og partikulærbaptister.
} 
antistrukturs rum og befinder sig derfor hævet over enhver menneskelig lovgivnings begrænsninger. $^{3}$

I lyset af at den protestantiske reformation i sin selvforståelse gjorde op med den hellige krigs begreb - i og med at den både afviste kirkens ret til at legitimere krig og gjorde op med den forestillingsverden, som korstogsafladen var funderet på - er det interessant, at man blandt de mest yderliggående protestanter kan iagttage en reformulering af korstogstanken og det formentlig som følge af netop opgøret med middelalderens tankeunivers. Op gennem middelalderen havde krigens religiøse og juridiske aspekter blot været delmængder af den retfærdige krigs universelle kategori. Korstogene, den kristne hellige krigs arketype, blev således legitimeret med henvisning både til religionen og til den af Gud indstiftede universelle lov. Men med den retslige diskurs' selvstændiggørelse og som følge af de dogmatiske stridigheder, reformationen bar med sig, blev den religiøst og den juridisk motiverede krig udskilt som komplementære legitimeringsformer. Juridiske argumenter kunne skelnes fra religiøse, og man kan derfor først fra det tidligt moderne betragte 'retslig krig' og 'hellig krig' som egentlig distinkte begreber (Johnson 1975, 8): Hvor den, der kæmper i en retslig krig, underkaster sig et universelt regelsæt, der ville gælde, 'selvom Gud ikke var til', forpligter den hellige krigers guddommelige opdrag ham derimod ud over den jordiske retfærdigheds grænser. Han skal ikke svare over for etikkens love, men kun over for Gud. Hvor man ifølge en mere traditionel læsning betragter adskillelsen af religion og politik, og dermed af hellige krige i klassisk forstand, som en direkte konsekvens af den protestantiske reformation, er det altså Baintons påstand, at netop denne adskillelse paradoksalt nok muliggjorde idéen om en hellig krig - begrundet i religionen alene - i sin reneste form.

Denne tese synes at hente bekræftelse hos Leighton, der i Speculum Belli Sacri netop lancerer et sådant skel mellem krigens etiske og religiøse motivationsfaktorer. Værket indledes med et afsnit om 'Krigens Onde', hvori Leighton beskriver dens rædsler og dens sammenhæng med synden. Krigen er syndens frugt og syndens sold. Som generelt fænomen er den et produkt af arvesynden, og konkrete konflikter hidrører fra konkrete, dennesidige synder, ligesom krigen i sin udøvelse også selv avler synd. På den anden side kan Gud ikke have delte meninger om et så afgørende fænomen som krig, og eftersom der findes talrige vidnesbyrd i Biblen på, at Gud både tillader og velsigner krige og krigere, kan det modsatte ikke også være sandt. Krig må altså under visse omstændigheder være tilladt. Så når Leighton pointerer, at den vise mand 'skyer enhver unødvendig krig', implicerer han også eksistensen af 'den nødvendige krig', som defineres i det følgende afsnit om 'Krigens Gode':

Notwithstanding all this, that hath been said of war; yet Warre well undertaken is not onely lawfull but also necessary; and that upon a two-fold ground, either upon the law of Nature and Nations, not repugnant to the Law of God, undertaken for the defence of ourselves or confederates; and this is called a Defensive War; (...) Or it is grounded upon the absolute command of God, for the revenging him upon his enemies, or the delivery of his friends; (Leighton 1624, 6)

Den nødvendige krig kan antage to former. Ligesom Augustin - der i Om Gudsstaden pointerer, at menneskets fald og dets deraf følgende modsætningsforhold til Gud og til

\footnotetext{
3 'Antinomisme' angiver her den holdning, at den herskende lov skal ophæves og eventuelt erstattes af en ny, og er kun indirekte forbundet til den filosofiske og den juridiske betydning af begrebet 'antinomi'.
} 
andre mennesker er grundlaget for dets krigeriske tilværelse i den jordiske stad (De civitate Dei $\mathrm{XV}, 4)$ - bruger Leighton sin negative karakteristik af krigen til at nå frem til den retfærdige krigs begreb: Krigen er et onde, men ikke altid er det største onde. Derfor må man føre krig for at afhjælpe et overgreb på retfærdigheden, og i den henseende er krigens udfald et gode. Men hvor retfærdige krige derfor altid er forsvarskrige, og af hensyn til proportionaliteten altid betragtes som sidste udvej, opererer Leigthon også med en legitim, offensiv krig. Oprindeligt havde puritanerne i overensstemmelse med The Thirty-Nine Articles, der udgjorde grundlaget for anglikanernes opfattelse af forholdet mellem krig og religion, kun omtalt krig som retfærdig krig, altså negativt, og derfor havde de heller ikke tillagt Det Gamle Testamentes eksempler på krige, ført på Guds bud, nogen gyldighed i en kristen kontekst (George 1984, 495). Leighton derimod betragter disse eksempler som eksempler til efterfølgelse og fuldbyrder dermed calvinismens rehabilitering af Det Gamle Testamente. For som det ovenstående citat viser, hævder han, at der ved siden af den retfærdige krig, der føres i henhold til naturloven, findes en hellig krig, der føres på Guds direkte bud.

Baintons tese om en særlig form for puritansk hellig krig er ikke uanfægtet. Således har hans skarpeste kritiker, religionshistorikeren James Turner Johnson, påpeget, at Bainton ikke har blik for forskelligheden i de argumenter for krig, som både puritanerne og deres modstandere fremførte (Johnson 1975, 144). Hvad værre er, hans opfattelse af korstogstanken som en lovløs eller antinomisk tilstand leder til en egentlighedsdyrkelse - idet enhver social konflikt ses som en afledning af dette bagvedliggende princip - der i bedste fald er fejlagtig og i værste fald farlig. Ifølge Johnson er etiske og religiøse legitimeringsfomer analoge og ikke antitetiske, og hellig krig praktiseres derfor aldrig uden en vis form for retslighed (Johnson 1997, 43. 101). Men skønt hellige krigere altså udmærket kan oscillere mellem etiske og religiøse motivationsfaktorer, kan man til Baintons forsvar fremhæve, at det ikke betyder, at det er dem lige meget, hvordan en krig begrundes. Tværtimod; den implicitte graduering, der er indeholdt i Leightons skelnen mellem en negativt defineret retfærdig krig og en positivt forkyndt hellig krig, mere end antyder, at det for den religiøse er helt afgørende, at etikken ikke kan stå alene. Men når jeg $\mathrm{i}$ det følgende vil søge at analysere den puritanske korstogstankes præmisser, skal det understreges, at jeg ikke nærer noget ønske om at komme Baintons revolutionsromantik til undsætning endsige forfalde til religiøs determinisme. Jeg betragter sammenfaldet af religiøse, politiske og socio-økonomiske faktorer - og ikke ét af disse delelementer - som udslagsgivende for konfliktens udbrud og forløb. ${ }^{4}$

\section{Hellig krig som verdslig askese}

Det jeg vil argumentere for er, at puritanismen og den puritanske korstogstanke var karakteriseret ved to grundlæggende elementer: en særlig handlingsmodus og en særlig tidsopfattelse. Den førstnævnte, som er i fokus i dette afsnit, betegner det, Max Weber har identificeret som den 'verdslige askese'. ${ }^{5}$ Eftersom hans analyser heraf i Die Protestantische Ethik und der Geist des Kapitalismus fra 1904 må anses for at være kendt stof, vil jeg nøjes med at skitsere hans hovedpointe: At etableringen af den vestlige kulturs

\footnotetext{
${ }^{4}$ For en gennemgang af forskningspositioner i tilgangen til borgerkrigen se Hill 1958, 14 og Russell 1973, 4.

${ }^{5}$ Jeg citerer fra Webers tyske tekstforlæg, men bruger den danske weberreceptions gængse begreber.
} 
altdominerende rationaliseringsform kan forklares i kraft af en særlig social praksis den verdslige askese - der opstod i reformerte kredse som følge af den måde, hvorpå de sociale aktører forholdt sig til den dobbelte prædestinationslæres radikalisering af teodicéproblemet: Ønsket om frelsesvished ledte de troende til at søge tegn i det dennesidige, som kunne befæste dem i, at de ikke var at tælle blandt de fortabte, og som dermed generede et særligt incitament til at udnytte de forhåndenværende vilkår bedst muligt. For når Gud har sat en i nogle bestemte kår, og der genereres en opfattelse af, at man kan få vished om ens frelsesstatus ved at tolke det udbytte, man er i stand til at få ud af disse kår, så er man også tilbøjelig til at maksimere dette udbytte i videst muligt omfang eller - hvis det viser sig umuligt - at ændre disse vilkår. Med andre ord: Både økonomisk vækst og social mobilitet kan ses som bivirkninger forårsaget af denne fortolkning af prædestinationslæren.

Den verdslige askese er dels interessant i denne sammenhæng, fordi Weber selv har udpeget 'de genuint puritanske revolutioner' som idealtypen på hellig krig som verdslig askese (Weber 1920, 553), og dels fordi den tjener til at anskueliggøre forskellen mellem den klassiske og den puritanske korstogstanke. Middelalderens korsfarere opfattede sig selv som enten pilgrimme eller - efter stiftelsen af de militær-religiøse ordener, hvoraf tempelherrerne og hospitalerne er det mest kendte - som munke. De var derfor i besiddelse af særlige privilegier og underlagt særlige forpligtelser. Nok kunne de i modsætning til andre pilgrimme og munke bære sværd; men deres hellige kald bandt dem også til en konkret opgave og ikke mindst til at iagttage en særlig kodeks i udførelsen heraf. For så vidt var der tale om askese, men vel at mærke ikke - på trods af at krig forekommer som en særdeles profan foreteelse - en verdslig askese. Som pilgrimme og munke var de nemlig adskilt fra den sociale omverden i rum og i tid. Korsfareren var ikke en almindelig kriger, men en 'Militia Christi', en Kristi Stridsmand, hvis pilgrimsstav eller glatragede isse og ikke mindst korstegn markerede ham som bærer af et helligt løfte og deltager i en hellig krig, der ikke fandt sted i timelighedens, men i evighedens perspektiv. I den puritanske korstogstanke opereres der derimod ikke med et sådant skel mellem soldatens hinsides kald og hans dennesidige forpligtelser. Mens middelalderens korsfarer i kraft af korstogsafladen kunne kæmpe og dø med henblik på retfærdiggørelse, befandt soldaten i den puritansk dominerede parlamentshær under den engelske borgerkrig sig principielt i en konstant uvished om sin frelsesstatus. Den sociale logik, som Weber afslører, tilsiger imidlertid, at udøveren af dødens håndværk ligesom enhver anden håndværker netop i kraft af denne uvished var henvist til en konstant søgen efter tegn på sin frelse i sine dennesidige, verdslige gerninger. Så længe nederlaget udebliver, kan den troendes frelsesbevidsthed ikke anfægtes. På det punkt bekræftes Webers analyse i Leightons Speculum Belli Sacri. For en af værkets helt centrale problemstillinger er, hvordan en hellig krig stiller nogle helt særlige krav til hærens organisering, til hærledelsens evne til at fastholde fokus - således at personlig vinding, letkøbte sejre eller udsigten til fred ikke skal skygge for krigens egentlige hensigt (Leighton 1624, 104. 315) - og sidst, men ikke mindst, til soldatens sindelag.

God will not accept or blesse the action (at least to that partie) before he blesse and accept the person: but the person being accepted, howsoever it fall out, it is a blessing to him (Leighton 1624, 24).

Krigen kan altså - uanset dens udfald - kun være hellig, for så vidt som den person, der udøver den, er at tælle blandt dem, 'der er velsignede og accepterede af Gud', altså 
hører de udvalgte til. Det betyder imidlertid også, at hvis man i krigens udfald søger tegn på ens frelsesstand, er sejren det eneste halmstrå, den troende kan klamre sig til. Derfor kæmper puritaneren heller ikke 'kun' for at blive frelst, men med henblik på at sejre, hvilket - alt andet lige - skaber bedre soldater. I den henseende synes Webers studier og Leightons værk at underbygge tesen om en 'protestantisk revolution' i 1600tallets udvikling af militære taktikker - båret af hærledere som den svenske Gustav Adolf i 30-årskrigens Tyskland, af Maurits af Nassau i Nederlandene og af Oliver Cromwell i England (Parrott 1992, 24).

\section{Fra etisk forpligtelse til politisk handling}

Michael Walzer, der har suppleret Baintons analyse af den hellige krigs revolutionære aspekter med Ernest L. Tuvesons studier af fremskridtstankens millennaristiske rødder i puritanismen, kritiserer Weber for at overse den helt afgørende forskel på individuelle og kollektive motivationsfaktorer. Hvor individets etik - dets forholden sig til sig selvpåvirker dets handlingsmodus som individ, har vi med studiet af forholdet mellem politik og religion snarere at gøre med individets forholden sig til og ageren som del af et fællesskab. Walzers kritik hviler på et lidt tyndt grundlag, fordi han helt overser, at Weber andetsteds, i "Zwischenbetrachtung: Theorie der Stufen und Richtungen religiöser Weltablehnung”, faktisk beskæftiger sig med krigen - politikkens radikaliserede udtryk - som netop en kollektivforeteelse. I analysen af forholdet mellem religion og politik er det springende punkt for Weber, hvorledes forløserreligionens broderskab af udvalgte kan forholde sig til politikkens afpersonificerede retslighed, der forudsætter, at alle - principielt - er lige for loven. For i dette forhold findes det helt afgørende skel mellem kirke og sekt. Kirken eller 'den organiske socialetiks' institutioner søger at komme overens med verden, både som natur og som socialitet. De lægger vægt på forløserreligionens universalistiske budskab og etablerer nogle rammer for religionens udøvelse, der har til hensigt at tilgodese de behov, der gælder i henhold til helheden. Den organiske socialetiks institutioner understøtter det eksisterende samfundsfællesskab, og derfor kendetegnes de som oftest også ved at være temmelig konservative. De er gået på kompromis med verden, og for at bevare balancen i dette kompromis har de en grundlæggende interesse $\mathrm{i}$ at sikre en stabilitet $\mathrm{i}$ deres forhold til de verdslige magthavere. Anderledes forholder det sig med sekterne eller det, som Weber kategoriserer under betegnelsen 'virtuositetsreligion'. De er per definition partikularistiske. Deres udgangspunkt er, at forløsningen ikke er enhver forundt. Derfor kendetegnes de også ved at være verdensafvisende. De behøver ikke gå på kompromis med verden, for de opfatter ikke sig selv som del af den. Hvis de agerer i verden, er det vel at mærke for at lave den om. Omsat til politisk handling er virtuositetsreligionen revolutionær, men den kan antage to forskellige udtryk: Mystikken og den verdslige askese (Weber 1920, 553).

Både mystikken og den verdslige askese eksisterer i modsætning til den organiske socialetik og har revolutionen som medie for politisk handling. Når Weber skelner mellem mystik og verdslig askese, bunder det $\mathrm{i}$, at hvor den verdslige asket er forpligtet på verden og på denne verdens love, betragter mystikeren efter hans opfattelse ikke sine handlinger i et dennesidigt perspektiv. I sin religiøse praksis repræsenterer mystikeren verdensafvisningens radikaliserede udtryk, og under 'normale' omstændigheder agerer han derfor slet ikke politisk. Først når en ny verden er i sin vorden, og det åbenbares, hvem der hører de frelste til, kan mystikeren træde i karakter - og når det sker, har den 
gamle verdens love ingen gyldighed mere. I sin beskrivelse af mystikkens politiske udtryk fremdrager Weber derfor anabaptisternes stiftelse af et jordisk tusindårsrige i Münster i $1534 \mathrm{og}$ pointerer, at en sådan bevægelse først giver mening i nærforventningens skær.

Dies ist sinnvoll dann möglich, wenn eschatologische Erwartungen eines unmittelbaren Anbruches des Weltalters der akosmistischen Brüderlichkeit aufflammen, wenn also der Glaube an die Ewigkeit der Spannung zwischen der Welt und dem irrationalen hinterweltlichen Reich der Erlösung ausfällt (Weber 1920, 553f).

Webers beskrivelse af anabaptisterne følger en generel tendens til at koble millennarisme med antinomisme, en kobling som gør det muligt for ham at opretholde det skel mellem mystikken og den verdslige askese, som er gennemgående i hans beskrivelse af virtuositetsreligionen. Spørgsmålet er imidlertid, om han ikke her - fordi det er ham så magtpåliggende at understrege den verdslige askeses særegenhed - overdriver denne modsætnings betydning. For betragter vi Speculum Belli Sacri, finder vi ganske vist også en kritik af anabaptisternes opfattelse af forholdet mellem krig og religion; men denne kritik retter sig ikke mod deres eskatologiske sindelag, men slet og ret mod deres pacifisme. At anabaptisterne ifølge Leighton med henvisning til næstekærligheden betragter enhver form for krig som syndig, skyldes efter hans opfattelse, at de forveksler forestillingen om den personlige fjende, 'inimicus', med den offentlige fjende, 'hostis', og overser, at fordringen om tilgivelse kun angår mennesket som enkeltindivid og ikke samfundet som fællesskab (Leighton 1624, 14). ${ }^{6}$ Men Leighton selv holder sig ikke tilbage med at henvise til sine egne eskatologiske forhåbninger. Som vi skal se i det følgende, opfatter han hellig krig som netop en eskatologisk foreteelse, og i den henseende er der altså - i modsætning til, hvad Weber hævder - ikke nogen umiddelbar forskel på det teologiske belæg for puritanernes og anabaptisternes opfattelse af forholdet mellem religion og politik.

Webers analyse af den verdslige askeses betydning for puritanernes opfattelse af forholdet mellem krig og religion er ikke forkert, men den er heller ikke fyldestgørende, og i den henseende har Walzer ret i sin kritik. For et aktørcentreret fokus kan forklare, hvorfor puritaneren i ønsket om at følge sit dennesidige kald ikke kan afstå fra at deltage og yde sit bedste i en krig; men Webers ensidige kobling af eskatologi og mystik afskærer ham også fra at forklare et helt afgørende aspekt af den puritanske korstogstanke. Som jeg vil argumentere for i det følgende afsnit, var det netop eskatologien, som gav den verdslige askese en forståelsesramme at komme til udtryk i som social handling. For det var i kraft af nærforventningstanken, at den individuelle frelse kunne relateres til frelsesaristokratiske kollektivs dennesidige rolle.

\section{Reformation og revolution}

I sine Forelcesninger over historiens filosofi argumenterer Hegel for, at den egentlige årsag til, at den franske revolution endte i terrorens vold, var, at den ydre, politiske frisættelse måtte forblive et abstrakt ideal, så længe franskmændene ikke havde gennemlevet reformationens indre emancipation (Hegel 1830, 535). Et af holdepunkterne i det

\footnotetext{
${ }^{6}$ Såvel Augustin som Calvin opererer med en lignende skelnen. Begreberne inimicus og hostis har jeg fra Carl Schmitt, hos hvem dette skel udgør en nøgle til ven/fjende-relationen (Schmitt 1932, 63).
} 
følgende vil ligeledes være forbindelsen mellem reformation og revolution - men mit fokus vil være anderledes. At reformationen påvirker revolutionens idé, er nemlig åbenlyst i puritanernes tilfælde. Men det jeg vil fokusere på er, hvorledes reformationens og revolutionens begreber i den periode, vi her beskæftiger os med, gennemgik en afgørende forandring.

Tager vi re-formationen på ordet, har den til opgave at gen-skabe troens oprindelige indhold og udtryk. I sin selvforståelse betegner den en tilbagevenden til en tid, før kirken reducerede troen på Kristus til gerningsretfærdighed. Noget lignende gør sig gældende med begrebet re-volution. Som Reinhart Koselleck har påpeget, er den betydning af ordet, som kommer til udtryk i titlen til Nikolaus Kopernikus' De revolutionibus orbium caelestium, som havde til hensigt at beskrive 'himmellegemernes kredsløb', den oprindelige. Ligesom det græske $\mu \varepsilon \tau \alpha \beta o \lambda \eta$ betegner det latinske 'revolvo' en cirkelbevægelse, og antikkens forestilling om en $\mu \varepsilon \tau \alpha \beta \mathrm{o} \lambda \eta \pi \mathrm{o} \lambda \iota \tau \varepsilon \iota \omega v$, en forskydning fra en styreform til en anden, var netop funderet på den opfattelse, at forfatningsformer afløser hinanden i et uendeligt kredsløb (Koselleck 1979, 70). Den tanke, at sådanne processer skulle være irreversible, fordrede en forskydning fra et statisk til et progressivt historiesyn, etableringen af en egentlig historisk bevidsthed, i hvilken dennesidige hændelser kan tildeles en selvstændig signifikans som netop irreversible begivenheder. Det er en sådan forskydning, jeg vil hævde kan påvises hos puritanerne, 100 år før den via oplysningsfilosofien fandt vej til den franske revolution.

\section{Endetidens komme}

Eftersom Paulus i 1. Thessalonikerbrev, det ældste kristne skrift overhovedet, besvarer det centrale spørgsmål - hvorfor de omvendte dør, når nu de er blevet lovet et evigt liv ved at henvise til den nært forestående opløftelse, kan vi ikke andet end antage, at forestillingen om verdens snarlige undergang må siges at have været til stede i kristendommen fra begyndelsen. Det er imidlertid nødvendigt at skelne mellem på den ene side den kendsgerning, at kristendommen med forestillingen om verdens undergang er født med en slags historiefilosofi, og på den anden side spørgsmålet om, hvordan denne opfattelse har påvirket kristendommens egen historie. Overordnet set findes der tre mulige fortolkninger af profetien om endetiden: nærforventningstanken, den realiserede eskatologi og den frelseshistoriske fortolkning. Ifølge nærforventningstanken, som den kommer til udtryk hos eksempelvis Paulus, står Herrens Dag for døren. Nærforventningstanken har været central i religionens konstitutive fase, men er sårbar, fordi dens forudsigelser sjældent holder stik. Derfor åbner de to andre udlægninger af læren om de sidste tider i højere grad det eskatologiske fortolkningsrum. Nært beslægtet med nærforventningstanken er den realiserede eskatologi, som hævder, at endetiden allerede er begyndt. Den kender vi fra Johannes' Åbenbaring, og netop åbenbaringens dunkle forudsigelser er den realiserede eskatologis medie. I den ses samtidens begivenheder som varsler om de retfærdiges snarlige opløftelse, og i den udpeges de tegn, de troende i fremtiden vil kunne kende Herrens Dag på. Man kan, alt efter hvordan man opfatter det dennesidige, drage forskellige konsekvenser af såvel nærforventningstanken som af den realiserede eskatologi. Begge fortolkninger lader jord og himmel mødes. Men det centrale i den realiserede eskatologi er, at den ved at udspænde endetidens forløb, således at det omfatter den dennesidige historie i sin helhed, også fordrer, at de troende forholder sig til denne historie. Sat i de eskatologiske begivenheders midte må den, der har ører at høre 
med, også vurdere og revurdere disse hændelser i deres sande kontekst.

\section{Den frelseshistoriske fortolknings dominans}

Det var imidlertid den frelseshistoriske fortolkning, den tredje udlægning af endetidens betydning, som skulle vise sig stærkest op gennem middelalderen. I sin selvforståelse adskiller den frelseshistoriske fortolkning sig ikke fra hverken nærforventningstanken eller den realiserede eskatologi. Også den anser dommens komme for at være uomgængelig. Reelt muliggør den imidlertid en udsættelse af Herrens genkomst på ubestemt tid. Både nærforventningstanken og den realiserede eskatologi åbnede for en nedvurdering af det dennesidige, som kun var vanskeligt forenelig med den verdslige øvrigheds interesser. Men den frelseshistoriske fortolkning skulle bygge på en radikal adskillelse af det dennesidige og det hinsides, som gjorde det muligt for kristendommen at forsone sig med verden. Den tilgodeså det krav om lydighed over for denne verdens øvrigheder, som både udtrykkes i de centrale skrifter (Rom 13,1ff.; Mark 12,17 par.), og som i sagens natur var nødvendig, for at kristendommen kunne komme overens med verden. Op gennem middelalderen blev forestillingen om såvel den verdslige, imperiums, som den gejstlige magts, sacerdotiums, autoritet funderet på denne adskillelse af jordeliv og himmerige, og derfor så ikke blot kejseren, men også kirken en klar interesse i at fastholde netop den fortolkning, der understøttede den eksisterende orden (Koselleck 1979, 22). ${ }^{7}$

Prisen for en overensstemmelse mellem imperium og sacerdotium var således, at forholdet mellem det dennesidige og det hinsides blev gjort statisk, og det er et af den frelseshistoriske fortolknings primære kendetegn, at den i bund og grund er historieløs. I den augustinske historiefilosofi, denne fortolknings formative udtryk, findes der inden for timelighedens kontinuum kun tre begivenheder af betydning: faldet, løftet og opfyldelsen. De er de eneste berøringspunkter mellem det dennesidige og det hinsides, og som følge af Guds almagt derfor også de eneste hændelser, som medfører egentlige forandringer i menneskets dennesidige tilværelse. I Helligåndens tid er mennesket således underlagt de vilkår, som Kristi legemliggørelse og offer har udstukket for dets tilværelse frem til dommen - vilkår, som ikke ændrer sig i kraft af dennesidige begivenheder. Historien er slut; de troende venter blot på dens fuldbyrdelse.

Til spørgsmålet om årsagerne til den moderne historiefilosofis opståen må kristendommen i denne sammenhæng altså siges at være en nødvendig, men ikke en tilstrækkelig forudsætning. ${ }^{8}$ Jeg vil således hverken anfægte, at skabelsestanken i metafysisk henseende betegner et nybrud, eller bestride, at denne forestilling genererede en form for bevidsthed, som også kan betegnes som 'historisk' - for så vidt som den enkelte i særlig grad vil besinde sig på sine dennesidige handlinger, når han konfronteres med skabelsestankens radikale transcendens: At han er udkastet i en verden, der vil forgå, så snart Gud slipper sit greb i den, og nedsænket i en syndighed, som kun Guds nåde vil kunne udfri ham fra. Det, jeg argumenterer for, er derimod, at den historiske bevidsthed som kollektivforestilling og dermed som politisk foreteelse først etableres, når der ind-

\footnotetext{
${ }^{7}$ Skønt den frelseshistoriske fortolkning havde sat eskatologiens urværk i stå, var middelalderkirkens forhold til millennarismen dog ambivalent, da dens magt også afhang af en fortsat reaktualisering af eskatologien.

${ }^{8}$ I problematikken omkring 'gnosis' og ‘ortodoksi' støtter jeg mig altså her til gnosis-tanken, der i skildringen af menneskets omverdensforståelse sætter konflikt over konsensus og endetidskamp over skabelsesberetning.
} 
føres en nærværende, nutidig og synlig forbindelse mellem det hinsidige og det dennesidige. Med andre ord er det nødvendigt at skelne mellem individets og fællesskabets tid. For i kraft af den dominerende frelseshistoriske fortolkning blev forestillingen om historiens fremadskriden sat på standby i flere århundreder fremover, og det er min påstand, at først med relanceringen af den realiserede eskatologi fik den verdslige historie et egentligt forløb, og jeg vil vise, at en sådan relancering fandt sted hos de engelske puritanere i 1600-tallet.

\section{Realiseret eskatologi som forventningshorisont}

Den ændring, jeg vil påvise hos puritanerne i 1600-tallets England, er den bevægelse fra en rumlig tidsforståelse til en tidslig rumforståelse, som ifølge Reinhart Koselleck kendetegner 'Neuzeit' . En rumlig tidsforståelse kender vi fra en klassisk ritualopfattelse, for idéen om ritualet som en genopførelse af urtidsbegivenheden er netop funderet på forestillingen om, at al virkelig forandring finder sted i det transcendente, og at mennesket udkastet i immanensen kun gennem ritualet kan vise sin taknemmelighed og dermed være medvirkende til, at det helliges kraft kanaliseres på rette måde. Et andet udtryk for en rumlig tidsopfattelse finder vi i den klassiske korstogstanke - i hvert fald i den form, den antog efter det første korstogs afslutning. Middelalderens korstog hentede deres legitimitet $\mathrm{i}$ Åbenbaringens beretning om endetidens store slag; men de gjorde det - netop som følge af korstogsafladens gradvise institutionalisering - først og fremmest $\mathrm{i}$ allegorisk og ikke i konkret betydning (Alphandéry \& Duphront 1995, 207). For den frelseshistoriske tankegang placerer skabelsens, inkarnationens og endetidens progressivitet uden for den menneskelige omverdens grænser. Disse historiske forandringer er ikke genstand for erfaringen, men etablerer erfaringens vilkår og kan kun selv erfares gennem en hensættelse til en anden tid, til en tid uden for tiden; i ordets egentlige forstand et andet 'tidsrum'.

En egentlig historisk bevidsthed er henlagt til en tidslig rumopfattelse, hvori rummet eller den menneskelige omverden både som natur og som socialitet betragtes som værende i forandring. Det betyder ifølge Koselleck, at forholdet mellem erfaring og forventning forskydes. Et traditionsbundet verdenssyn - som jeg kalder en rumlig tidsopfattelse - kendetegnes ved, at erfaringen i høj grad sætter forventningens rammer. For skønt muligheden for at erfare noget nyt, der ikke kan indordnes i erfaringens allerede kendte kategorier, altid er til stede - hvilket betyder, at forventning aldrig vil kunne reduceres til erfaring - kendetegnes traditionen netop ved at søge at minimere denne mulighed. Neuzeit derimod er karakteriseret ved en reel eller oplevet erfaring af, at erfaringen i mindre og mindre grad kan appliceres på forventningen, og at mennesket derfor må besinde sig på forandringen. Denne forskydning af erfaringen har også betydning for opfattelsen og indretningen af de politiske institutioner. Hvor traditionen søger at indordne det sociale liv i en fast, hierarkisk orden, som afspejler og understøtter uforanderligheden, betyder forventningens voksende betydning på erfaringens bekostning i Neuzeit, at også det sociale legemes liv indordnes i tidslighedens irreversible før og efter. Kosellecks mestertræk er, at han pointerer nødvendigheden af at skelne mellem individuel og kollektiv tid (Schanz 1996, 107). Tilværelsens tidslige dimension er afgørende

\footnotetext{
${ }^{9}$ Begrebet 'Neuzeit' er en præcisering af begrebet 'modernitet' og betegner den overgang til det moderne, som kendetegnes ved etableringen af egentlig tids- eller historiebevidsthed (Andersen 1999, 65).
} 
for ethvert menneske til enhver tid: Alene i kraft af, at vi skal dø, kan vi slet ikke lade være med at forholde os til, hvordan vi færdes i verden. Men med den kollektive tidsopfattelse forholder det sig anderledes.

Freilich haben weder Augustin noch Heidegger ihre Fragen auf die Zeit der Geschichte ausgedehnt. Ob sich die jedenfalls intersubjektiven Zeitstrukturen der Geschichte hinreichend aus einer Daseinsanalyse ableiten lassen, bleibe als Frage hier offen (Koselleck 1979, 335).

I socialiteten forandres de begreber, vi opfatter og omfatter vores omverden med, og dermed også vores opfattelse af socialiteten selv. ${ }^{10}$ Det gælder også vores intersubjektive tidsopfattelse, som den historiske bevidstheds opståen viser er i evig forandring. For at forstå, hvordan vi agerer som sociale individer, er vi derfor nødt til at bevæge os ud over de blotte eksistentielle vilkår og studere, hvorledes vore begreber opstår og forandres. Et er at studere, hvorledes etikken kan tilbageføres til døden som menneskeligt vilkår - noget andet er, hvordan politikken påvirkes af idéen om verdens ende. Med udgangspunkt $i$ denne skelnen mellem individets og historiens tid vil jeg derfor gå over til at vise, hvorledes man i 1600-tallets England kan iagttage, hvordan en egentlig historiebevidsthed blev etableret med relanceringen af den realiserede eskatologi.

\section{Puritanismens opståen i nærforventningens skær}

Den kritik, jeg rettede mod Weber i det foregående afsnit, skal ses som en videreførelse af den kritik, Koselleck med sin skelnen mellem individets og historiens tid retter mod Augustin og Heidegger. I sin iver efter at identificere puritanerne med den verdslige askeses idealtype glemmer Weber nemlig at forklare, hvilken intersubjektiv handlingsramme det puritanske frelsesaristokrati agerede inden for. Nok kan Webers begreb om den verdslige askese anskueliggøre, hvorfor den hellige kriger kæmper så indædt - også uden gerningsretfærdigheden som lokkemad - men det sætter ikke kollektivets handling ind $i$ en meningsfuld sammenhæng. Den verdslige askese forklarer den personlige motivation til at kæmpe og dø, men ikke hvorfor man skal kæmpe og dø for en konkret sag. Martin Luther opfattede en sådan sammenhæng som helt unødvendig, fordi enhver krigs legitimitet findes i pligten til lydighed over for den verdslige øvrighed. Men ligesom den lutherske kaldstanke hos puritanerne undergik en forandring fra den organiske socialetiks 'anstaltsforpligtelse' til en verdslig askese, således ændrede synet på de udvalgtes fællesskab sig også. Så længe den enkelte lever i uvished om sin egen frelse, er pligten til lydighed tilstrækkelig. Men når frelsesaristokratiets pagtsfællesskab kan identificeres, bliver det også nødvendigt at fastslå, hvilken kollektiv forpligtelse dette fællesskab skal opfylde i det dennesidige for at leve op til sin pagtsforpligtelse. I revolutionen fandt den verdslige askese et kollektivt politisk udtryk, der forudsatte, at den politiske handling som social foreteelse også blev sat i perspektiv. Et sådant perspektiv tilbød den realiserede eskatologi.

I sin oprindelige form var protestantismen lige så uforenelig med forestillingen om en realiseret eskatologi, som den var det med den klassiske korstogstanke. Skønt Luther anså endetiden for at være nært forestående, var det ham magtpåliggende at afvise en-

\footnotetext{
${ }^{10}$ Koselleck kritiseres for, at hans skelnen mellem begreb og omverden eller sprog og virkelighed er temmelig unuanceret (Ifversen 2003, 25) - en kritik, jeg dog ikke forholder mig til i denne korte præsentation.
} 
hver brug af en sådan indsigt til at forbryde sig mod denne verdens orden, som Gud havde sat øvrigheden til at vogte. I den henseende er Luthers to-regimentelære et produkt af den augustinske frelseshistorie, som middelalderkirkens forestillingsverden byggede på. Luther radikaliserede skellet mellem det verdsliges og det gejstliges domæner; men han bevægede sig ikke ud over den frelseshistoriske to-verdensmetafysiks grundlæggende struktur. Inden for de reformerte kirker skete der derimod et afgørende nybrud, ikke som en direkte følge af Calvins lære, men måske snarere på grund af den homogenisering af ellers vidt forskellige retninger inden for protestantismen, som de eksileredes ufrivillige ophold i Schweiz, i Rhinlandet og i Nederlandene havde forårsaget; og i den puritanske bevægelse, der udsprang blandt disse eksilprotestanter, spiller eskatologien fra begyndelsen en meget fremtrædende rolle.

I deres eksil på kontinentet efterlod puritanismens grundlæggere sig to afgørende skriftlige vidnesbyrd om deres virke. Det ene var Genevebibelen, den mest omfattende oversættelse til engelsk siden Wycliffes. Det andet var John Foxes Acts \& Monuments eller The Book of Martyrs, som forfatteren færdiggjorde og udgav i 1563 i Strasbourg, og som i det efterfølgende århundrede skulle blive den mest læste bog i England efter Bibelen. Det var netop i kraft af The Book of Martyrs, at endetidsforestillinger - i første omgang som passiv nærforventning, og senere som decideret realiseret eskatologi skulle spille en afgørende rolle for puritanerne og langt ind i anglikanernes rækker. Foxe identificerer kirken, de troendes fællesskab, med martyrerne, og bogen er én lang beretning om dem, som op gennem historien har stået som blodvidner om troen på Kristus. Det er deres 'gerninger' og deres 'vidnesbyrd', han fortolker, og nøglen til denne fortolkning er Johannes’ Åbenbaring, der skildrer martyrernes sande kirkes historie. Helt i Åbenbaringens ånd betragter Foxe de hændelser, skriftet beretter om, som allegorier, der - hvis man som han forstår at bryde koden - beretter om konkrete, dennesidige begivenheder. Foxe deler historien fra Helligåndens komme til Dommens Dag op i spand på godt 300 år og hævder - helt i overensstemmelse med eskatologiens generelle logik - at vi lever i den sidste af disse perioder, en tid hvori den katolske kirkes modstandere, først og fremmest protestanterne, udgør martyrernes sande fællesskab.

Fifthly and lastly, after this time of Antichrist, reigning in the Church of God by violence and tyranny, followeth the reformation and purging of the church of God, wherein Antichrist beginneth to be revealed, and to appear in his colour, and his Antichristian doctrine to be detected, the number of his Church decreasing, and the number of the true Church increasing (Foxe 1583, I, 5).

The Book of Martyrs evne til at fortolke lidelserne ind i en meningsfuld ramme tilgodeså tilsyneladende et helt afgørende behov blandt Foxes trosfæller, og værket var den primære inspirationskilde for en lang række forfattere i de efterfølgende generationer, som også søgte at afsløre korrespondensen mellem Åbenbaringens forudsigelser og konkrete, dennesidige begivenheder. Blandt de utallige, der har set Åbenbaringen i et allegorisk lys, kan Foxe i betydning formentlig kun sammenlignes med Joachim af Fiore (Jørgensen 1989, 147). Skønt de begge betragtede kirken som en fordærvet frugt, er der - udover de rent konfessionelle forskelle på en katolsk munk fra det 12. århundrede og en protestantisk prædikant fra 1500-tallet - en helt afgørende fortolkningsmæssig tilgang, der adskiller de to forfattere. For hvor det jordiske tusindårsrige for Joachim stod umiddelbart før sin virkeliggørelse, hørte det for Foxe fortiden til. Fra sit eksil så han en verden midt i endetidens blodige kamp, hvor de hellige var omringet af fjender "talløse 
som havets sand" ( $\AA$ b 20,8), og de troende kunne kun sætte deres lid til Guds snarlige indgriben. ${ }^{11}$ Derfor kan man ikke tale om en handlingsrettet, realiseret eskatologi hos Foxe, højst om en nærforventningstanke med alle dens fatalistiske undertoner. Men hvor hovedvægten i The Book of Martyrs således ligger på opløftelsen af de rettroende gennem deres lidelser, kan man fra slutningen af det 16. århundrede imidlertid iagttage en begyndende ændring i denne passivistiske grundholdning.

\section{Realiseret eskatologi: Fra martyrkult til tusindårsrige}

Efter reformationens gennemførelse i England og Skotland, og efterhånden som Englands politiske magt og anseelse steg, så fremtiden langt lysere ud ved overgangen til det 17. århundrede. Dermed var der også et potentiale til stede for en anden, langt mere positiv fortolkning af samtiden i Åbenbaringens lys (Gregersen 1989, 180). Fra hos Foxe at have været et offer for Satans rænker bliver de troendes fællesskab nu snarere en aktør i endetidens store slag. Ligesom Johnson har påpeget, at opfattelsen af forholdet mellem krig og religion i 1600-tallets England var langt mere kompleks, end Baintons analyse lader antyde, har Susanne Gregersen vist, hvorledes de eskatologiske forventninger ikke blot var forbeholdt puritanerne, men at vi faktisk finder nogle af de mest repræsentative udtryk herfor blandt meget fremtrædende anglikanere: James VI Stuart af Skotland, der senere blev James I af England, og som indædt bekæmpede puritanernes nonkonformisme, og Joseph Mede, der, da konflikten spidsede til, valgte side til fordel for anglikanerne og kongemagten. ${ }^{12}$

James Stuart affattede i 1588 skriftet $A$ Fruitful Meditation, hvori han på baggrund af skildringen af endetidskampen $\mathrm{i}$ Åbenbaringens kapitel 20 gav sit bud på protestantismens særlige opdrag. Ligesom Foxe anså James Stuart tusindårsriget for at være forbi. Men hvor Foxe blot antyder et lønligt håb om de frelstes snarlige opløftelse, er scenen her sat til det endelige opgør med Fjendens utallige horder.

For since we see God hath promised not only in the world to come, but also in this world, to give us victory over them, let us in assurance hereof strongly trust in our God, cease to mistrust his promise, and fall through incredulitie or unbelief (James I Stuart 1588, III, 8).

Hvor den Hellige Stad i den klassiske korstogstanke var hellig, fordi den repræsenterede noget bagvedliggende, fordi det jordiske Jerusalem tjente til ihukommelse af dets himmelske pendant, så fandt korstogstankens relancering i 1600-tallets England sted i et opgør med en sådan allegorisk virkelighedsopfattelse. Ligesom frelseshistoriens toleddede struktur blev erstattet af konkrete, dennesidige begivenheder, trådte den konkrete geografi i stedet for det religiøse verdensbilledes repræsentative. Hos James I udgør det belejrede Sion eller Jerusalem derfor ikke et 'center out there', men den konkrete, nærværende, protestantiske stat, og i Leightons fortolkning af Åbenbaringens guddom-

\footnotetext{
${ }^{11}$ Først mod enden af Foxes værk udtrykkes der håb om de retfærdiges snarlige opløftelse. Det gælder især de afsnit, der omtaler Dronning Elizabeth - et træk, der forstærkes i 1570-udgaven af Foxes værk.

${ }^{12}$ Blandt andet på baggrund af at eskatologiske forhåbninger var så bredt accepterede i anglikanske kredse, fremhæver Gregersen, at pagtsforestillingen og ikke millennarismen var den puritanske bevægelses primære kendetegn (Gregersen 1989, 179). Jeg vil dog hævde, at det netop var millennarismen - om end det er nødvendigt at skelne mellem moderat og rabiat millennarisme - der gav pagtsforestillingen sit meningsindhold.
} 
melige kald om at nedbryde Babylon er det helt konkret pavernes Rom, der tænkes på. Ud af den selvopofrende martyrkult opstår der altså hos James Stuart en militant protestantisme, hvori nuet gøres til den hellige tid og England til det nye helligsted, til det Ny Jerusalem. At en sådan forestilling, som også er fremtrædende i den puritanske korstogstanke, ytres i James Stuarts skrift, viser, hvor tæt parterne faktisk var på hinanden. Det bidrager også til at forklare, hvorfor der alle modsætninger til trods ikke før borgerkrigens udbrud var tegn på, at puritanerne nærede noget ønske om at henrette kongen og indføre en republik. Det var tværtimod deres håb, at kongen skulle søge at samle alle protestanter i en fælles alliance mod de katolske habsburgere og pavemagten (Walzer $1965,282)^{13}$ - en forhåbning, der med al tydelighed afspejles i indledningen til Speculum Belli Sacri, hvor Leighton dedikerer værket til blandt andet Charles Stuart, hvis navnefællesskab med Karl den Store han ser som et tegn på, at Gud har givet den kommende konge en helt særlig rolle i kampen mod det fordærvede Rom (Leighton 1624, viiii). $^{14}$

Ligesom puritanerne i James Stuarts skildring af England som det Ny Jerusalem kunne finde vidnesbyrd om et åndsfællesskab trods de ydre omstændigheder, var Clavis Apocalyptica, Apokalypsens nøgle - Joseph Medes værk fra 1627 - så velanset, at det på parlamentets foranledning blev oversat til engelsk i 1643, midt under borgerkrigen, på trods af at dets forfatter støttede kongemagten. Hvem han var, anfægtede altså tilsyneladende ikke rigtigheden af det, han skrev, og værkets betydning understreges desto mere af, at det i den anglikanske restauration - efter protektoratets fald i 1660 - blev brugt til at lokke de fortabte, puritanerne, tilbage i kirkens fold. Som titlen antyder, udgør det en detaljeret gennemgang af, hvorledes skildringen i Johannes' Åbenbaring kan relateres til samtidige begivenheder. Men det afgørende er, at i modsætning til, hvad der gjorde sig gældende hos Foxe og til dels også hos James Stuart, mener Mede ikke blot at have afkodet Åbenbaringens gåde og fundet den systematiske sammenhæng mellem Guds frelsesplan og den dennesidige historie, men han ophæver det dennesidige tusindårsrige til præsent realitet. For Mede betegner Dommedag ikke én dag, men et kontinuum strakt over mange år:

A day, I say, beginning from that first partial, and as it may be termed, morning judgement of Antichrist, by the glorious appearance of our Lord in a flame of fire, and finishing at length after the reign of a thousand years, granted to the new Jerusalem, his most holy spouse on this earth, and the total destruction of new enemies hereafter to arise, when the great day is declining, and Satan again loosed, by the universal resurrection and judgement of all the dead (Mede 1627). ${ }^{15}$

Det Ny Jerusalem, Mede taler om, betegner Kristi 'helligste mage på denne jord'. Der er altså ikke tale om hverken den skjulte Gudsstad i eksil eller om det Ny Jerusalem, som først kommer til syne med "en ny himmel og en ny jord" ( $\mathrm{b} b 21,1)$, men om netop et

\footnotetext{
${ }^{13}$ Hvor stor betydning, puritanerne tillagde dette aspekt, understreges af, at parlamentet i alle våbenhvileudspil under borgerkrigen forlangte engelsk deltagelse i de kontinentale religionskrige (Hill 1958, 132).

${ }^{14}$ Idéen nød bred støtte. Således indleder Francis Bacon i 1624 sit sidste værk med en opfordring til Charles om på baggrund af sit kejserlige navn at erklære krig mod Spanien (Bacon 1624, 469). Karolus-motivet er gennemgående i politisk idéhistorie og kendes også fra Luthers Vom Kriege wider die Türken fra 1529 (Luther 1529, 116).

${ }^{15}$ Jeg citerer fra Bransby Coopers 1833-oversættelse af den latinske grundtekst.
} 
konkret, dennesidigt fællesskab af hellige, som skal være "Guds og Kristi præster og være konger med ham i de tusinde år" (Åb 20,6). Derfor er der hos Mede heller ikke tale om hverken en frelseshistorisk to-verdensmetafysik eller en nærforventningstanke, men om en realiseret eskatologi, der forpligter den troende til aktiv handling. Min pointe er, at denne forskydning i tidsopfattelsen muliggjorde en forskydning i opfattelse af forholdet mellem krig og religion - og dermed en reformulering af korstogstanken. Clavis Apocalyptica udkom kun et år efter Speculum Belli Sacri, og det er næppe tilfældigt, at en lignende tankegang gør sig gældende hos Leighton, når han i sin skelnen mellem en retfærdig krig, der føres i henhold til den universelle naturlov, og en hellig krig, der føres på Guds direkte bud, netop henviser til, at en sådan ordre er blevet udstedt i og med Johannes' Åbenbaring. Protestanterne behøver altså ikke vente på tegn fra Gud om at gå i offensiven - de kan blot læse de tegn, der allerede er til stede i samtiden. Ligesom Mede hævdede, at udgydelsen af de syv vredesskåle (Åb 16) vil nå et foreløbigt klimaks med Gustav Adolfs sejr over huset Habsburg, således ser Leighton i skildringen af kampen mod Skøgen - om hvem det siges, at hun "er den store by, som har herredømmet over jordens konger" ( $\AA$ b 17,18) - en utvetydig opfordring til at engagere sig i 30-årskrigen. For såvel Mede som for Leighton udgør det guddommelige kald om at nedbryde Babylon ikke en allegorisk skildring af et opgør hinsides deres samtids virkelighed, men en helt konkret opfordring til her og nu at deltage i det endelige opgør mod Guds fjender og gå mod katolicismen og Rom.

I sin martyrberetning identificerede Foxe troens fællesskab med martyrernes kirke, som han i sin samtid mente blev repræsenteret af de engelske protestanter. Hos James I og senere hos Leighton og Mede blev dette fællesskab gjort til en egentlig eskatologisk aktør i det slag, der skal finde sted umiddelbart før Dommen, og i kraft af forestillingen om det dennesidige tusindårsriges præsente realitet fik denne kobling af udvælgelsestanken og endetidsforestillingen en entydig dennesidig dimension. Dermed rakte den kamp, de helliges samfund skulle deltage i, ikke blot ind i evigheden, men ind i det dennesidiges fremtid. Fra i den klassiske korstogstanke at have været et ritual blev den hellige krig nu en egentlig dennesidig handling, en religiøs ideologi. Dermed fuldbyrdedes også den bevægelse, Koselleck beskriver med sit begreb om Neuzeit, en bevægelse fra utopi til ideologi. Utopien er kendetegnet ved den fiksering af eskatologien, som kommer til udtryk i den frelseshistoriske to-verdensmetafysik, hvor enhver handling finder sted i evighedens perspektiv. Naturligvis handler mennesket også som socialt væsen i sådanne sammenhænge; men dets handlinger er sat inden for nogle institutionelle rammer, der afspejler et himmelsk ideal, som i kraft af sin eviggyldighed også tilstræber uforanderlighed. Ideologien derimod retter sig mod det dennesidige. Dens indre spænding mellem 'er' og 'bør' bygger på etableringen af en tidslig differens i det sociale, som overfører den irreversibilitet, der hersker på ontogenesens domæne, til fylogenesens. På samme måde som det individuelle legemes udvikling aldrig kan sættes i stå og aldrig kan spoles tilbage, blev det sociale legemes historie nu til dennesidig historie.

\section{Den puritanske korstogstankes betydning}

I første halvdel af 1600-tallet opstod der blandt de engelske puritanere en særlig opfattelse af forholdet mellem krig og religion. Denne opfattelse, som jeg i det ovenstående har benævnt den puritanske korstogstanke, adskilte sig på to centrale områder fra andre fortolkninger af dette forhold. For det første gik den mod tidsånden. Hvor man på 
kontinentet ved 30-årskrigens afslutning gennem stadfæstningen af den statslige suverænitet gjorde den juridisk legitimerede krig enerådende, fastholdt puritanerne forestillingen om en hellig krig, legitimeret gennem religionen alene. For det andet adskilte den sig fra middelalderens opfattelse af forholdet mellem krig og religion, idet den puritanske korstogstanke var funderet på foreningen af to grundelementer - den verdslige askese og den realiserede eskatologi - der i virkning og betydning i allerhøjeste grad har præget det moderne.

Den puritanske korstogstankes kobling af forskellige motivationsfaktorer var ikke gnidningsløs, og netop dens iboende spænding mellem individuelt og kollektivt incitament, mellem elitær og folkelig protestantisme og mellem forskellige udlægninger af realiseret eskatologi medvirkede i sidste ende til, at det protektorat, puritanerne grundlagde, aldrig viste sig levedygtigt. Men dermed ikke være sagt, at den puritanske korstogstankes betydning ophørte med protektoratets fald. Én følge af restaurationen i 1660 var ganske vist, at de puritanere, der blev i England, måtte vælge den kontemplative vej og gå i indre eksil. Derved blev det ideologiske, kollektivt handlingsrettede og dennesidige element igen fjernet fra den institutionelle religions domæne: Betegnelsen Kristi Stridsmand blev igen reduceret til en allegori. Men forestillingen om et fællesskab af udvalgte, i besiddelse af en historisk mission, og dermed i besiddelse af særlige privilegier og særlige forpligtelser, levede videre blandt dem, der i stedet valgte det ydre eksil. Den yderliggørelse af pagtstanken og den dennesidiggørelse af historien, som kendetegnede den puritanske korstogstanke, skulle i allerhøjeste grad komme til at gøre sig gældende $\mathrm{i}$ forhold til forestillingen om nationen som en historisk entitet. De samfund i den nye verden, som puritanere på flugt fra forfølgelser grundlagde $i$ årene op til borgerkrigen og under restaurationen, blev af deres stiftere betragtet som små, dennesidige tusindårsriger, og igennem dem kan den stadigt levende forestilling om Amerika som en udvalgt nation føres tilbage til den puritanske korstogstanke.

\section{Litteratur}

ALPHANDÉRY, PAUl \& AlPHONSE DUPHRONT

1995 La Chrétienté et l'idée de Croisade, Éditions Albin Michel, Paris.

ANDERSEN, NIELs ÅKERSTRØM

1999 Diskursive analysestrategier. Foucault, Koselleck, Laclau, Luhmann, Nyt fra Samfundsvidenskaberne, København.

BACON, FRANCIS

1624 "Considerations Touching a War With Spain", in: id., The Works of Francis Bacon vol. XIV, Longmans Green, Reader \& Dyer, London 1874, 469-505.

BAINTON, RONALD H.

1943 "Congregationalism: from the Just War to the Crusade in the Puritan Revolution", in: id., Collected Papers in Church History II, Hodder and Stoughton, 1964, 248-274.

FOXE, JOHN

1583 The Acts and Monuments of John Foxe, AMS Press Inc., New York 1965; (1563-, 1570-, 1576- og 1583-udgaverne er tilgængelige via http://www.hrionline.ac.uk/foxe/; set 24.10.2006).

George, Timothy

1984 "War and Peace in the Puritan Tradition", Church History 53 (4), 492-503. 


\section{Korstogstankens reformulering}

GREGERSEN, SUSANNE

1989 "Det Ny Jerusalem: Guds folk i en engelsk, puritansk tradition”, in: Anna Marie Aagaard, ed., Det ny Jerusalem, Guds by og de skiftende forventninger, Anis, Frederiksberg, 177-208.

Hegel, GeORG WiLhELm FriedRich

1830 Vorlesungen über die Philosophie der Geschichte, Suhrkamp Verlag, Frankfurt/M. 1970.

HILL, CHRISTOPHER

1958 Puritanism and Revolution, Studies in the interpretation of the English Revolution of the 17th Century, Penguin Books, Harmondsworth 1986.

IFVERSEN, JAN

2003 "Om den tyske begrebshistorie", Politologiske Studier 6 (1), 18-34.

JAMES I STUART

1588 A Fruitful Meditation http://www.jesus-is-lord.com/kjreve2b.htm (set 24.10.2006).

JOHNSON, JAMES TURNER

1975 Ideology, Reason and the Limitation of War, Princeton University Press, New Jersey.

1997 The Holy War Idea in Western and Islamic Traditions, The Pennsylvania State University Press, Pensylvania.

JøRGENSEN, NINNA

1989 "Fra klosterspiritualitet til kommunalpolitik", in: Anna Marie Aagaard, ed., Det ny Jerusalem, Guds by og de skiftende forventninger, Anis, Frederiksberg, 143-176.

KOSELLECK, REINHART

1979 Vergangene Zukunft, zur Semantik Geschichtlicher Zeiten, Suhrkamp, Frankfurt a.M.

LEIGHTON, ALEXANDER

1624 Speculum Belli Sacri: or the Lookingglasse of the Holy War, Amsterdam.

LUTHER, MARTIN

1529 "Vom Kriege wider die Türken", in: Martin Luthers Werke 30, Hermann Böhlaus Nachfolger, Weimar 1909, 81-148.

Mede, JosePH

1627 Clavis Apocalyptica, London 1833; http://www.historicist.com/mede/title.htm (set 15.4.2006).

PARROTT, DAVID

1992 "The Military Revolution in Early Modern Europe", History Today 42 (12), 21-27.

RUSSELL, CONRAD, ED.

1973 The Origins of the English Civil War, Macmillan Press, London.

SCHANZ, HANS-JøRGEN

1996 Det historiske, refleksioner over historie og metafysik, Forlaget Modtryk, Århus.

SCHMITT, CARL

1932 Det politiskes begreb, Hans Reitzels Forlag, København 2002.

SIMPSON, ALAN

1955 Puritanism in Old and New England, The University of Chicago Press, Chicago.

TUVESON, ERNEST L.

1968 Redeemer Nation: The idea of America's Millennial role, The University of Chicago Press, Chicago. 
WALZER, MiCHAEL

1965 The Revolution of the Saints, a study in the origin of radical politics, Harvard University Press, Massachusetts.

Weber, Max

1904 "Die protestantische Ethik und der Geist des Kapitalismus", in: id., Gesammelte Aufsätze zur Religionssoziologie, J.C.B. Mohr, Tübingen 1922, 17-206.

1920 "Zwischenbetrachtung: Theorie der Stufen und Richtungen religiöser Weltablehnung", in: id., Gesammelte Aufsätze zur Religionssoziologie, J.C.B. Mohr 1922, Tübingen 536573.

Morten Brænder

Ph.d.-stipendiat

Institut for Statskundskab

Aarhus Universitet 